\title{
Trade Effects of Geographical Indications on Turkish Agricultural Products and Foodstuff
}

\author{
Burçak Müge Vural ${ }^{1, a, *}$ \\ ${ }^{1}$ Department of Economics, Faculty of Business Administration, Dokuz Eylül University, 35220 İmir, Turkey \\ *Corresponding author
}

\begin{tabular}{l|l}
\hline A R T I C L E I N F O & A B S T R A C T \\
\hline $\begin{array}{l}\text { Research Article } \\
\begin{array}{l}\text { Received : 05/02/2021 } \\
\text { Accepted : 01/05/2021 }\end{array}\end{array}$ & $\begin{array}{l}\text { Environmental concerns together with social and ethical issues raise consumers' interest in } \\
\text { sustainable production and consumption practices. With rising trends of fair trade and high } \\
\text { popularity of organic and local production in recent years, the demand for geographical indication } \\
\text { registration has also increased by agricultural producers as a way of transmitting further information } \\
\text { to raise reputation of their products. This research aims to assess the impact of geographical } \\
\text { indications on export performance of Turkish agricultural products and foodstuffs. Findings reveal } \\
\text { that geographical indications increase export revenues. Results communicate an important message } \\
\text { to policy makers to promote the protection of geographical indications. }\end{array}$ \\
\hline $\begin{array}{l}\text { Eeographic indications } \\
\text { toxport performance }\end{array}$
\end{tabular}

Export performance

Extensive-intensive margins

Foodstuffs

Agriculture

muge.tunaer@deu.edu.tr

(i) https://orcid.org/0000-0002-4252-6276|

(c) (1) (9) This work is licensed under Creative Commons Attribution 4.0 International License

\section{Introduction}

Developing countries rely heavily on agricultural production in their production and exports. Despite economic importance of the sector to the developing countries, chances of raising farmers' income remains low due to low price and income elasticities of farm products in international markets. Recently, agricultural economists identified how food markets are affected by product attributes, quality and heterogeneous consumer preferences and concerns (Unnevehr et al., 2010). Increasing awareness of consumers have rendered consumers' willingness to pay increase for goods that are differentiated by quality. Thus, the way of delivering information on product attributes also became an important component of advertisement policies.

Geographical indication (GI) has appeared as one important labelling tool to transmit information regarding the product origin and characteristics to the consumers. A GI, by definition, is a denotation for products with a specific geographical origin and possessing qualities or a reputation that are due to that origin (Ingram et al., 2020). According to TRIP's definition geographical indications 'identify a good as originating in the territory of a Member, or a region or locality in that territory, where a given quality, reputation or other characteristics of the good is essentially attributable to its geographical origin' (TRIPs, Article 22.1). Similarly, Article 3 of the Decree Law No. 555 in Turkish Legislation defines geographic indication as 'a sign indicating the origin of a product that possesses a specific quality, reputation or other characteristics attributable to that place, area, region or country of origin'.

GI implies certain product characteristics and quality, that requires a traditional know how and specific inputs of the terroir. Establishing the product's reputation is often the result of collective investment over many generations, that differentiates the product and increases the added value of it. Product differentiation and increased value added ensure facilitated access to markets (Beletti and Marescotti, 2011). Thus, geographic indications increase rural income and contribute to rural development (For some recent studies on the link between rural development and GI policy making, readers may refer to Beletti et al. (2017); Çukur and Çukur (2017); Kan et al. (2016); Yenipınar et al. (2014); Mercan and Üzülmez (2014); Kan, et al. (2012); Barham and Sylvander (2011); Orhan (2010); Thiedig and Sylvander (2000)). Neo-classical economic perspective, on the other hand, considers GIs as collective monopolies entitled to monopolistic profits (Bramley and Kirsten, 2007). Accordingly, public policies are justified on grounds to ensure smooth operation of the market mechanism. Policies are often aimed at elimination of information asymmetry, in order to prevent both consumer fraud and unfair competition (Barjolle et al., 2011). While providing a legitimate bases for implementation of geographic indication protection policies, geographic 
indications have been suggested and employed as an important policy tool for income generation by raising added value and improving market access, in particular for developing countries.

There have been few attempts to measure the trade impact of geographical indications. Most of these empirical investigations rely on some variants of gravity model. Employing the multiplicative structure of gravity model and focusing on EU countries, Sorgho and Larue (2014) found significant impact of geographical indications on trade. Trade creation impact appears when both exporter and importer countries have geographical indications. Yet, they also found evidence of trade diversion when exporting country has geographical indications but importing country does not. Agostino and Trivieri (2014) provided further evidence on positive trade effect of geographical indications, with special focus on European wine exports. Decomposing price and quantity effects, Agostino and Trivieri (2016) showed that geographical indications are associated with higher price premium of exported wine. Yet volume of exports increases only towards high income destination markets. A recent study by Raimondi et al. (2020) extended this early literature by using a different empirical approach based on panel data econometrics. In line with previous research, findings of Raimondi et al. (2020) revealed that geographical indications raise product price, since product with geographical indications are perceived as high quality by consumers. In addition, geographical indications have positive trade effect on both extensive and intensive trade margins for exporting country. However, on the import side, geographical indications have some weak trade reducing impact when registered only in importer country. Given limited number of studies mainly focusing on EU geographical indications policy impact on trade flows, the research aims to contribute to the literature by providing further evidence for the trade effects of geographical indications on Turkish agricultural products and foodstuff.

With legislative enactment of geographical indication protection in 1995 in the Decree Law no 555, geographical indications are registered by Turkish Patent and Trademark Office. In line with rising trend of sustainable food production and consumption, there has been a surge in applications for geographical indication registration and the number of protected geographical indications in Turkey. Despite fast rise in applications, especially after 2016, the number of registered geographical indications remains low compared to worldwide trading partners (There has been a significant rise in the number of geographic indications registration after 2016. While 9.75 registered GIs observed per year on average until 2016, the number has become 82.86 per year until then. Kan and Kan (2020), sensibly, attributes this fundamental rise in GI registration to changes in Turkish Industrial Property Law. The significant rise has been interpreted as an indication of both the ease of registration procedure and increase the consumer and producer awareness and interests for GI's products'.). According to statistical data on the number of geographical indications in force by legal means provided by WIPO, Turkey remains far behind many EU member states and developing countries. In comparison to 5256 geographical indications in force for EU - 28, the number of Turkish geographical indications in force is 487 by the year 2019 (WIPO, 2020). The number of Turkish geographical indications remain significant even when compared to EU-28. Yet, the number of Turkish geographical indications registered in the EU are not satisfactory. There are 25 Turkish geographic indications registered in the EU, and Turkey is ranked $18^{\text {th }}$ among EU member states registered in the EU (see Table 1). The largest share of all geographical indications in force by legal means in Turkey belongs to agricultural products and foodstuffs product category (slightly more than 75\%). Furthermore, quadrupling number of applications in last four years indicate rising popularity of geographical indications among Turkish agricultural producers as a market-based tool for added value creation.

Given the rising importance of geographical indications, this research aims to assess the economic impact of geographical indications on export performance of Turkish agricultural products and foodstuffs. Turkey is one of the major World exporters of dried fruits, vegetables and nuts, as well as possessing comparatively advantageous position in exports of cereals, fresh fruits and vegetables. Yet, many of Turkish agricultural products and foodstuffs, that are unique with their flavour and local production techniques, have not geographical indication registry. Furthermore, Turkey remains far behind many of her trading partners in geographical indications labelling. Bearing in mind the wide gap between Turkey and her many trading partners in terms of registry of geographical indications, potential gains remain still high not only for Turkish producers, but also consumers and rural communities. Econometric investigations to quantify impact of geographical indications policy impact on export performance would yield important policy implications.

The rest of the paper is organised as follows. Section 1 describes the data and methodology employed to account for the impact of geographic indications on extensive and intensive trade margins. Section 2 presents empirical findings. Section 3 makes the concluding remarks.

Table 1. Number of GI products registered in the EU by each Member State

\begin{tabular}{l|c|l|c|l|c|l|c}
\hline $\begin{array}{c}\text { Member } \\
\text { State }\end{array}$ & $\begin{array}{c}\text { Number of } \\
\text { GIs }\end{array}$ & $\begin{array}{c}\text { Member } \\
\text { State }\end{array}$ & $\begin{array}{c}\text { Number of } \\
\text { GIs }\end{array}$ & $\begin{array}{c}\text { Member } \\
\text { State }\end{array}$ & $\begin{array}{c}\text { Number of } \\
\text { GIs }\end{array}$ & $\begin{array}{c}\text { Member } \\
\text { State }\end{array}$ & $\begin{array}{c}\text { Number of } \\
\text { GIs }\end{array}$ \\
\hline Austria & 57 & Estonia & 2 & Ireland & 15 & Poland & 36 \\
\hline Belgium & 40 & Spain & 377 & Italy & 879 & Portugal & 210 \\
\hline Bulgaria & 71 & Finland & 10 & Lithuania & 15 & Romania & 72 \\
\hline Cyprus & 24 & France & 764 & Latvia & 4 & Sweden & 27 \\
\hline Czechia & 43 & Greece & 277 & Luxembourg & 5 & Slovenia & 44 \\
\hline Germany & 179 & Croatia & 66 & Malta & 3 & Slovakia & 24 \\
\hline Denmark & 13 & Hungary & 84 & Netherlands & 34 & & \\
\hline
\end{tabular}

Source: GI View, https://www.tmdn.org/giview/ 
Table 2. Number of GI products aggregated at HS 2-digit level (EU27+Turkey)

\begin{tabular}{c|lc}
\hline DC & \multicolumn{1}{|c}{ Product Category } & Number of GIs \\
\hline 02 & Meat and Edible Meat Offal & 389 \\
\hline 03 & Fish and Crustaceans, Molluscs and other Aquatic Invertebrates & 62 \\
\hline 04 & $\begin{array}{l}\text { Dairy Produce; birds' eggs; natural honey; edible products of animal origin, not elsewhere } \\
\text { specified or included }\end{array}$ & 349 \\
\hline 06 & Trees and other plants, live; bulbs, roots and the like; cut flowers and ornamental foliage & 5 \\
\hline 07 & Vegetables and Certain Roots and Tubers, Edible & 368 \\
\hline 08 & Fruits and Nuts, Edible; Peel of Citrus Fruit or Melons & 216 \\
\hline 09 & Coffee, Tea, Mate and Spices & 70 \\
\hline 12 & $\begin{array}{l}\text { Oil seeds and oleaginous fruits; miscellaneous grains, seed and fruit, industrial or } \\
\text { medicinal plants; straw and fodder }\end{array}$ & 5 \\
\hline 15 & $\begin{array}{l}\text { Animal or Vegetable Fats and oils and their cleavage products; prepared animal fats; } \\
\text { animal or vegetable waxes }\end{array}$ & 155 \\
\hline 17 & Sugars and Sugar Confectionary & 26 \\
\hline 18 & Cocoa and cocoa preparations & 2 \\
\hline 19 & Preparations of cereals, flour, starch or milk; pastrycooks' products & 313 \\
\hline 22 & Beverages, Spirits, and Vinegar & 42 \\
\hline 25 & Salt; sulphur; earths, stone; plastering materials, lime and cement \\
\hline
\end{tabular}

DC: HS 2-Digit Code, Source: Author's own calculations based on data provided by European Database of Origin and Registration and Turkish Patent and Trademark Office.

\section{Data and Empirical Strategy}

Empirical analyses focus on Turkish exports of agricultural products and foodstuff to 27 European Union member countries, over the years 1996 - 2019. There are two basic reasons why we focus on trade between Turkey and the EU members. First, EU is the largest trading partner of Turkey, accounting for $49.5 \%$ of Turkish exports in general and more than $30 \%$ of Turkish agricultural products and foodstuff exports specifically. It is, thus, of particular concern for Turkey to draw policy implications to enhance Turkish trade with EU whenever there exist potential trade creation effects. Second, European Database of Origin and Registration permitted to count the number of GIs per each EU member country from the year 1996 to 2019. A comparable dataset for Turkish GIs is provided by Turkish Patent and Trademark Office, that allowed us to do the same computations to extract Turkish GI data at HS 6-digit level. At the time of data extraction (2020) total number of registered GIs in EU and Turkey equals 2,013, of which 1,507 belongs to EU and 506 registered by Turkey. When aggregated, HS 6-digit GI products are categorised under 12 broader HS 2-digit sectors. Thus, the empirical strategy focuses on $14 \mathrm{HS} 2$-digit sectors. Number of GI products aggregated at HS 2-digit level are given in the Table 2.

Following Raimondi et al. (2020), author attributed each of the registered Turkish GIs between years 1996 2019 to their corresponding HS 6-digit class manually. Bilateral export data at HS 6-digit level come from UN COMTRADE database. Following Cadot et al. (2011), we rely on Theil index decomposition to identify intensive and extensive margins. Intensive margin accounts for the variation in export values because of a change in volume of trade in existing export product categories. Extensive margin, on the other hand, reflects variation in export values due to variation in the number of new products (product range) or new markets.

Even though Turkey and EU have Customs Union agreement, the Customs Union is limited to industrial products and does not cover agricultural products. Therefore, we used bilateral effectively applied tariff at six - digit product lines that are drawn from WITS-TRAINS data source. A measure of import tariff for each HS 2-digit sector is constructed by calculating simple average of effectively applied tariff at HS 6-digit. In addition, nontariff trade barriers are proxied by notifications of SPS measures provided by WTO I-TIP database.

Following Raimondi et al. (2020), our empirical strategy tests the trade effects of geographical indication on Turkish agricultural exports, through a decomposition of country product trade data to their respective extensive and intensive trade margins, also considering export prices. The benchmark specification of the empirical model is written Eqn. 1.

Where, $\ln V_{x m i t}$ represents the dependant variable that alternately becomes one of our main variables of interest; (1) value of exports in the food product line that belongs to an HS 2-digit sector $(i)$ from exporting country $(x)$ to importing country $(m)$ in time $(t),(2)$ extensive / intensive margins. Parameter $\beta \mathrm{s}$ are estimated coefficients of the geographical indication variables, that account for quality and reputation of the product. The set of GI policy indicators $\left(G I^{\prime}{ }_{\text {mit }}, G I^{\prime}{ }_{\text {xit }}\right.$ and $\left.G I^{\prime}{ }_{\text {xmit }}\right)$ are specified as follows: Eqn.2(a), Eqn.2(b) and Eqn.2(c).

$$
\begin{aligned}
& \ln V_{\text {xmit }}=\beta_{0}+\beta_{1} \mathrm{GI}_{\text {xit }}+\beta_{2} \mathrm{GI}_{\text {mit }}+\beta_{3} \mathrm{GI}_{\mathrm{xmit}}+\gamma \mathrm{T}_{\mathrm{xmit}}+\mathrm{fe}_{\mathrm{mt}}+\mathrm{fe}_{\mathrm{xt}}+\mathrm{fe}_{\mathrm{xm}}+\mathrm{fe}_{\mathrm{it}}+\mathrm{fe}_{\mathrm{t}}+\varepsilon_{\mathrm{xmit}} \\
& \text { Eqn. } 1 \\
& \mathrm{GI}_{\text {mit }}^{\prime}=\mathrm{GI}_{\text {mit }} \mathrm{XN}_{\text {mit }} \\
& \mathrm{GI}_{\text {mit }}=\left[\begin{array}{c}
1, \text { if importer } \mathrm{m} \text { has GIs and exporter } \mathrm{x} \text { has not } \\
0 \text {, otherwise }
\end{array}\right. \\
& \mathrm{GI}_{\mathrm{xit}}^{\prime}=\mathrm{GI}_{\mathrm{xit}} \mathrm{XN}_{\mathrm{xit}} \\
& \mathrm{GI}_{\text {mit }}=\left[\begin{array}{c}
1, \text { if exporter } \mathrm{x} \text { has GIs and importer } \mathrm{m} \text { has not } \\
0 \text {, otherwise }
\end{array}\right. \\
& \text { Eqn.2(a) } \\
& \mathrm{GI}_{\mathrm{xmit}}^{\prime}=\mathrm{GI}_{\mathrm{xmit}} \mathrm{x}\left(\mathrm{N}_{\mathrm{xit}}+\mathrm{N}_{\mathrm{mit}}\right) \\
& \mathrm{GI}_{\mathrm{xmit}}=\left[\begin{array}{c}
1, \text { if importer } \mathrm{m} \text { and exporter } \mathrm{x} \text { have GIs } \\
0 \text {, otherwise }
\end{array}\right.
\end{aligned}
$$


Here, $N_{\text {mit }}$ and $N_{x i t}$ are the number of geographic indications in sector $i$ in the importing country $m$, and exporting country $x$. Following Sorgho and Larue (2014), we employed number of geographic indications in a given country-product line, instead of dummy variable approach. This specification of geographic indications policy indicators allows us to account for differences in the number of geographical indications across countries for a given year and changes in the number of geographical indications over time. Three scenarios are identified to capture the impact of GI policy indicators. $G I^{\prime}{ }_{m i t}$ represents the first scenario under which only the importer country has GIs in a given product line. $G I^{\prime}{ }_{x i t}$ accounts for the situation when only exporter country has GIs in a given product line. Finally, $G I^{\prime}{ }_{x m i t}$ accounts for the scenario where both exporting and importing countries have GIs in the given product line.

The terms $f e_{m t}, f e_{x t}, f e_{x m}, f e_{i t}, f e_{t}$ identify importer - time, exporter - time, country - pair, product line - time, and year fixed effects respectively. The term $T_{x m i t}$ stands for trade policy related trade costs (i.e. tariffs and non-tariff trade barriers). Finally, $\varepsilon_{x m i t}$ denotes the error term.

Poisson Pseudo Maximum Likelihood (PPML) estimation technique is employed to estimate the econometric model specified in Eqn. 1. PPML estimator allows us to account for the zero trade flows (Santos Silva and Teneyro, 2006) as well as the problem of heteroscedastic and non-normal residuals (Santos Silva and Tenreyro, 2011). In addition, as a robustness check, we adopted Instrumental Variables (IV) approach to account for potential endogeneity bias. Following Raimondi et al. (2020), in the IV regressions the number of GIs is instrumented by the average number of GIs in adjacent industries. Adjacent industries are defined as those belong to the same HS 2-digit industry, excluding the instrumented HS 6-digit product line.

Under the empirical framework followed, the following hypotheses are tested:

H1: GI policy indicators have trade creation effect.

Geographical indications are often perceived as a sigh for higher quality or authenticity of the of the product by consumers. Thus, introduction of new GIs is hypothesised to increase trade. If the consumers of the importing country value geographical indications, introduction of new GIs by the exporter country should have demand enhancing effect. Positive and significant coefficients to the GI policy indicators are interpreted as indication of trade creation effect.

$\mathrm{H} 2$ : GI policy indicators have trade diversion effect.

In case of either exporting (importing) country has GIs, but importing (exporting) country has not, trade may have depressed because of several reasons. First, consumers living in country without GIs may not be willing to pay for the price premium associated with geographic indication and decrease demand towards differentiated GI products. Second, when exporting country has not GIs, but the importing country has, it may become harder for the exporting country to compete on the basis of quality. Thus, GIs of the importing country may divert trade from exporting countries without GIs towards exporting countries with GIs. Finally, introduction of new GIs may create home-bias effect possibly because GI products are most appreciated at home. Negative and significant coefficients to the GI policy indicators support trade diversion hypothesis.

In order to check for robustness of the results against endogeneity bias due to possible reverse causality, IV regressions approach is employed as suggested by Raimondi et al. (2020). IV regressions are estimated using Least Square with Dummies (LSVD) estimator. In the IV regressions, the number of GIs is instrumented by the average number of GIs in adjacent industries as explained before. The regression specified by equation (1) is estimated for export values at HS 6-digit product level.

In order to check the validity of suggested instruments, first stage IV regressions are estimated. Suggested instruments must be; (1) uncorrelated with the error term, and (2) correlated with the endogenous variable. First stage IV regressions test the validity of instruments based on these two conditions.

\section{Empirical Findings}

Empirical findings regarding the impact of GIs on Turkish agricultural products and foodstuff exports to EU are based on PPML estimations are explained in this section. Main findings of the econometric analyses are presented in Table 3.

Table 3. PPML Estimation Results - GI Effects on Turkish Agricultural Products and Foodstuff Exports to EU (1996 - 2019)

\begin{tabular}{c|cccc}
\hline \multirow{2}{*}{ Dependent Variable } & Extensive Margin & Intensive Margin & \multicolumn{2}{c}{ Exports } \\
\cline { 3 - 5 } & $(1)$ & $(2)$ & HS 6-Digit (3) & HS 2-Digit (4) \\
\hline$G I^{\prime}{ }_{\text {xit }}^{\prime}$ & $0.030^{* *}$ & $0.050^{* *}$ & $0.081^{* *}$ & $0.046^{*}$ \\
$G I^{\prime}{ }_{\text {mit }}$ & 0.011 & 0.002 & 0.040 & 0.008 \\
$\ln (1+$ tariff $)$ & $0.018^{* *}$ & $0.011^{* *}$ & $0.084^{* *}$ & $0.055^{* *}$ \\
$\ln (1+S P S)$ & $-0.88^{* *}$ & $-0.89^{* *}$ & $-1.02^{* *}$ & $-0.68^{*}$ \\
$f e_{m t}$ & $-0.64^{* *}$ & $-0.76^{* *}$ & Yes & $-0.62^{* *}$ \\
$f e_{x t}$ & Yes & Yes & Yes & Yes \\
$f e_{x m}$ & Yes & Yes & Yes & Yes \\
$f e_{i t}$ & Yes & Yes & Yes & Yes \\
N. of Obs. & Yes & Yes & 14,662 & 8,694 \\
Adjusted $R^{2}$ & 14,662 & 14,662 & 0.52 & 0.48 \\
\hline
\end{tabular}

*,**,*** indicate significance at $90 \%, 95 \%$ and $99 \%$ confidence levels, respectively. 
Column (1) reports the results for extensive export margins. Positive and significant coefficient to the GI effect when only exporter or both countries have GIs, indicates that GI increases the range of traded goods (extending trade to new product lines. The impact of GI seems even stronger for the intensive export margins (see column (2)). Extensive and intensive margins are estimated at HS 6-digit level which allows us to diminish possible aggregation bias. Employing dummy variables interacting with the sum of GIs to construct GI policy indicators allows us to capture the marginal effects of introducing GIs. Introduction of new GIs (by Turkey alone, by the importing country alone or by both countries) increases the volume of already traded sectors. When new GIs introduced by either Turkey alone or both Turkey and the importing country, new product lines open up for trade and Turkish export range enlarges. Overall, trade effects of GI appear positive and statistically significant on extensive and intensive export margins.

Considering the impact of GIs on Turkish exports at HS 6-digit level, adoption of new GI has statistically significant trade creating impact. Introduction of new GIs by Turkish producers increase export performance of Turkish agricultural products and foodstuff. This may be interpreted as transmission of information regarding geographical indication differentiate Turkish products and increase their reputation. European consumers value differentiated products and demand for greater variety. As Turkish products become more reputable, the range and value of exports to EU increase. Coefficients at HS 6-digit level are greater in magnitude and appear with stronger significance compared to coefficients estimated for HS 2 digit level. This may be attributed to possible aggregation bias. Estimates at HS 2-digit level also confirm trade creation impact of GIs.

When compared to the results from previous studies, our results support their findings of trade creation when both importer and exporter countries have GIs (Raimondi et al., 2020; Sorgho and Larue, 2014). When exporter has GIs, but importer does not our results associate with Sorgho and Larue's (2014) finding of trade creation effect for intra-EU trade. However, impact of GIs for the same scenario (when exporter has GIs, but importer does not) turns out to be depressive on extra-EU trade (Raimondi et al., 2020; Sorgho and Larue, 2014). It is important to mention that extra-EU trade estimations in these studies are conducted by using the country level GI data.
Measurement of GIs at the country level, instead of country-product level, may have reduced reliability of the coefficients and significance of estimation. There does not seem a statistical relationship between Turkish exports and GIs introduced by the importing country, when Turkey does not have GIs.

Finally, impact of trade policy related trade costs (nontariff barriers and import tariffs) imposed by EU countries appear negative and statistically significant on Turkish exports. This indicates trade diverting impact of tariffs and SPS measures imposed on Turkish agricultural product and foodstuff exports.

In order to check for robustness of our results against endogeneity bias due to possible reverse causality, IV regressions approach is followed as suggested by Raimondi et al. (2020). IV regressions are estimated using Least Square with Dummies (LSVD) estimator. In the IV regressions, the number of GIs is instrumented by the average number of GIs in adjacent industries as explained before. The regression specified by equation (1) is estimated for export values at HS 6-digit product level. Table 4 shows results obtained from first stage of IV regressions, and Table 5 shows results from robustness checks. Column (1) shows estimation results of LSVD and column (2) reports the estimated parameters of IV regression.

In order to check the validity of suggested instruments, the first stage IV regressions are estimated. Suggested instruments must be; (1) uncorrelated with the error term, and (2) correlated with the endogenous variable. First stage IV regressions test the validity of instruments based on these two conditions. First stage F-statistic values are above the critical value suggested by Stock and Yogo (2005), rejecting the null hypothesis of weak instruments.

Results obtained from second stage IV regressions are analogous to the PPML estimated parameters and remain robust. A noteworthy difference is that the insignificant coefficient of GIs by importing country turns out to be negative and remain insignificant. A possible trade diverting impact of GIs may be suspected, as suggested by previous literature yet results remain statistically insignificant. Finally, of the suggested hypotheses under the empirical framework, there has found statistically significant evidence to support first hypothesis that GI policy indicators have trade creation effect. However, our results do not yield any specific conclusions regarding the second hypothesis on trade diverting impact of GI policy indicators.

\section{Table 4. First Stage IV Regressions}

\begin{tabular}{|c|c|c|c|}
\hline Dependent Variable & $\mathrm{GI}_{\text {xit }}^{\prime}$ & $\mathrm{GI}_{\text {mit }}^{\prime}$ & $\mathrm{GI}_{\text {xmit }}^{\prime}$ \\
\hline Instrumented $G I_{x i t}^{\prime}$ & $0.58 * *$ & $0.02 *$ & 0.008 \\
\hline Instrumented $G I^{\prime}{ }_{m i t}$ & $0.04 *$ & $0.60 * *$ & 0.01 \\
\hline Instrumented $G I^{\prime}{ }_{x m i t}$ & 0.00 & $0.05^{*}$ & $0.54 * *$ \\
\hline $\ln (1+$ tariff $)$ & 0.28 & $-0.16^{*}$ & 0.09 \\
\hline $\ln (1+S P S)$ & 0.11 & $-0.10^{*}$ & 0.14 \\
\hline$f e_{m t}$ & Yes & Yes & Yes \\
\hline$f e_{x t}$ & Yes & Yes & Yes \\
\hline$f e_{x m}$ & Yes & Yes & Yes \\
\hline$f e_{i t}$ & Yes & Yes & Yes \\
\hline N. of Obs. & 14,662 & 14,662 & 14,662 \\
\hline Adjusted $R^{2}$ & 0.24 & 0.28 & 0.22 \\
\hline F - statistic & 1124.39 & 989.08 & 1032.11 \\
\hline
\end{tabular}

1124.39 
Table 5. Robustness Checks - GI Effects on Turkish Agricultural Products and Foodstuff Exports to EU (IV Estimations)

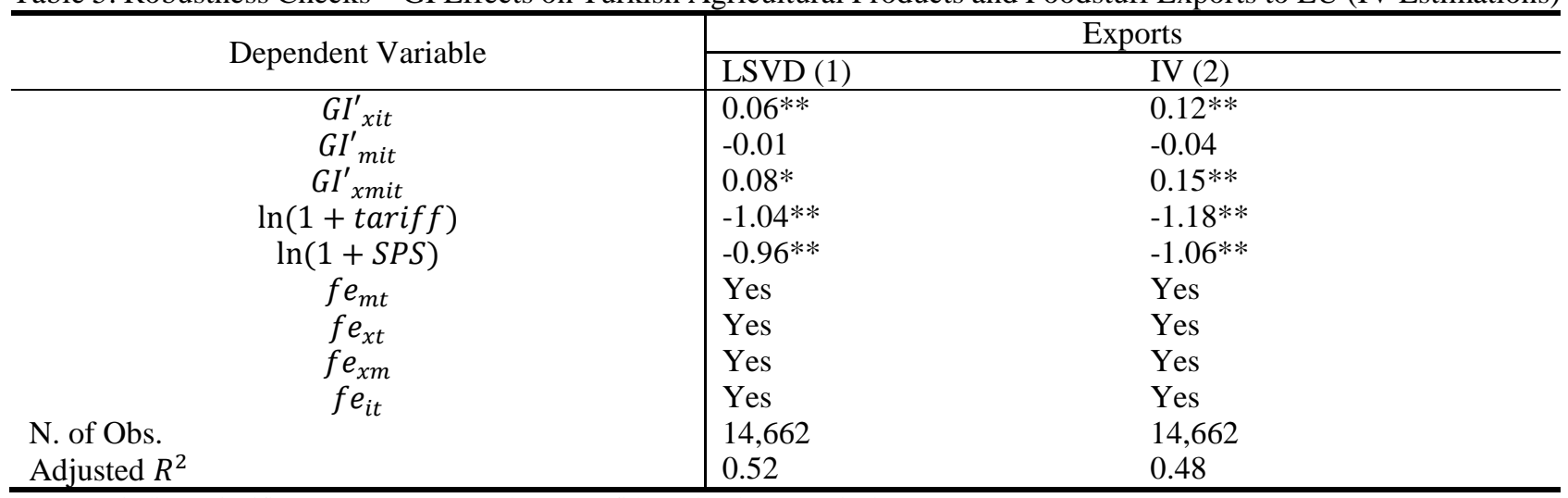

$*, * *, * * *$ indicate significance at $90 \%, 95 \%$ and $99 \%$ confidence levels, respectively.

\section{Concluding Remarks}

GIs recently emerged as a very popular tool of transmitting information on product origin and its peculiar characteristics to the consumers. While decreasing information asymmetry between producers and consumers on qualifications of the product, GI labelling also helped to change the structure of market for agricultural products towards a monopolistically competitive one. To the extent that differentiated product appreciated by the consumers, consumers' willingness to pay increased. Considering developing countries reliance on agricultural exports in international trade, GI labelling has gained further importance as a policy tool to generate income by raising added value and improve market access.

This paper investigated the quantitative impact of geographical indications on export performance, with specific reference to Turkish exports to EU members. Following the empirical structure suggested by Raimondi et al. (2020), Turkish exports of agricultural products and foodstuff to 27 European Union member countries are analysed, over the years 1996 - 2019. Data provided by European Database of Origin and Registration and Turkish Patent and Trademark Office allowed us to work at a level of disaggregation at country - product line.

Our results indicate trade creating impact of GIs on Turkish exports driven by both extensive and intensive margins. Statistical significance of positive coefficient to the Turkish GI registry suggests that European consumers value differentiated products and increase their demand for greater variety. As Turkish products become more reputable, the range and value of exports to EU increase. This research did not find any evidence for trade diverting impact of GIs. Our results are robust. Overall, trade creating effects of GI suggest that Turkish exporters of agricultural products and foodstuff could improve their market access and gain higher margins in the EU market by investing in product differentiation strategies.

\section{References}

Agostino M, Trivieri F. 2014. Geographical Indication and Wine Exports. An Empirical Investigation Considering the Major European Producers. Food Policy, 46: 22 -36. https://doi.org/10.1016/j.foodpol.2014.02.002

Agostino M, Trivieri F. 2016. European Wine Exports Towards Emerging Markets. The Role of Geographical Identity. Journal of Industry. Competition and Trade, 16: 233 - 256. https://doi.org/10.1007/s10842-015-0210-z
Barham E, Sylvander B (Eds). 2011. Labels of Origin for Food: Local Development, Global Recognition, CAB International, Wallingford. . ISBN-13: 9781845933524.

Barjolle D, Sylvander B, Thevenod - Motted E. 2011. Public Policies and Geographical Indications. In: Barham E, Sylvander B (Editors). Labels of Origin for Food: Local Development, Global Recognition, CAB International, Wallingford. pp. 92 - 105. ISBN-13: 9781845933524.

Beletti G, Marescotti A. 2011. Origin Products, Geographical Indications and Rural Development. In: Barham E, Sylvander B (Editors). Labels of Origin for Food: Local Development, Global Recognition, CAB International, Wallingford. pp. 75 - 91. ISBN-13: 9781845933524.

Beletti G, Marescotti A, Touzard J-M. 2017. Geographical Indications, Public Goods and Sustainable Development: The Roles of Actors' Strategies and Public Policies. World Development, 98: 45 - 57.

Bramley C, Kirsten JF. 2007. Exploring the Economic Rationale for Protecting Geographical Indicators in Agriculture. Agrekon, 46(1): 47 - 71. https://doi.org/10.1080/03031853. 2007.9523761

Cadot O, Carrere C, Strauss - Kahn V. 2011. Export Diversification: What's Behind the Hump? The Review of Economics and Statistics, 93(2): 590 - 605. https://doi.org/ 10.1162/REST_a_00078

Çukur F, Çukur T. 2017. Coğrafi İşaretli Ürünlerin Kırsal Kalkınma Açısından Değerlendirilmesi: Muğla İli Örneği. Turkish Journal of Agricultural Economics, 23(2): 187 - 194. https://doi.org/10.24181/tarekoder.364914

Ingram V, Hansen ME, Bosselmann AS. 2020. To Label or Not? Governing the Costs and Benefits of Geographic Indication of an African Forest Honey Value Chain. Frontiers in Forests and Global Change, Sept. (3): 102.

Kan M, Gülbuçuk B, Küçükçongar M. 2012. Coğrafi İşaretlerin Kırsal Turizmde Kullanılma Olanakları. KMÜ Sosyal ve Ekonomik Araştırmalar Dergisi, 14(22): 93 - 101.

Kan M, Kan A, Gülbuçuk B, Peker K. 2016. Türkiye'de Yerel Ürünlerin Bölgesel Kalkınma Dinamikleri içindeki Önemi. In: Peker AE (Ed.) Bölgesel Kalkınma, Paradigma Akademi, Çanakkale, Türkiye. pp. 231 - 280. ISBN: 978-605-82909-0-7

Kan M, Kan A. 2020. Qualitative and Quantitative Analysis of the Geographical Indication System in Turkey. Journal of Global Innovations in Agricultural Sciences, 8(2): $114-123$. https//doi.org/10.22194/JGIASS/8.899

Mercan ŞO, Üzülmez, M. 2014. Coğrafi İşaretlerin Bölgesel Turizm Gelişimindeki Önemi: Çanakkale İli Örneği. Dokuz Eylül Üniversitesi İ̈BF Dergisi, 29(2): 67 - 94.

Orhan A. 2010. Yerel Değerlerin Turizm Ürününe Dönüştürülmesinde 'Coğrafi İşaretlerin' Kullanımı: İzmit Pişmaniyesi Örneği, Anatolia: Turizm Araştırmaları Dergisi, 21(2): $243-254$. 
Raimondi V, Falco C, Curzi D, Olper A. 2020. Trade Effects of Geographical Indication Policy: The EU Case. Journal of Agricultural Economics, 71(2): 330 - 356.

Santos Silva J, Tenreyro S. 2006. The Log of Gravity. Review of Economics and Statistics, 88(4), 641 - 658. https://doi.org/ 10.1162/rest.88.4.641

Santos Silva J, Tenreyro S. 2011. Further Simulation Evidence on the Performance of the Poisson Pseudo - Maximum Likelihood Estimator. Economics Letters, 112(2): 220 - 222. https://doi.org/10.1016/j.econlet.2011.05.008

Sorgho Z, Larue, B. 2014. Geographical Indication Regulation and Intra-trade in the European Union. Agricultural Economics, 45(S1): 1- 12.

Stock J, Yogo M. 2005. Testing for Weak Instruments in Linear IV Regression. In: Andrews, D. W. K. (Ed.). Identification and Inference for Econometric Models, $1^{\text {st }}$. Ed.; Cambridge University Press: New York, U.S., pp. $80-108$.

Thiedig F, Sylvander B. 2000. Welcome to the Club? An Economical Approach to Geographical Indications in the European Union. Agrarwirtschaft, 49 (12): 428 - 437.

Turkish Patent and Trademark Office (TPO) Geographic Indications and Designations of Origin Database. Available from: https://www.ci.gov.tr/veri-tabani (accessed on 15.01.2021).
UN Comtrade Database (COMTRADE). Available from: https://comtrade.un.org/data/ (accessed on 16.12.2020).

Unnevehr, L.; Eales, J.; Jensen, H.; Lusk, J.; McCluskey, J.; Kinsey, J. 2010. Food and Consumer Economics. American Journal of Agricultural Economics, 92(2), 506 - 521. doi: 10.1093/ajae/aaq007

World Integrated Trade Solution - Trade Analysis and Information System (WITS-TRAINS). Available from: https://wits.worldbank.org/tariff/trains/countrybyhs6product.aspx?lang=en\#apl_T (accessed on 12.01.2021).

World Intellectual Property Indicators (WIPO) Statistics Database. Available from: https://www3.wipo.int/ipstats/ index.htm?tab=geographical (accesses on 04.01.2021).

World Trade Organization Integrated Trade Intelligence Portal (WTO I-TIP). Available online: https://i-tip.wto.org/goods/ Forms/ProductViewNew.aspx?data $=$ default (accessed on 16.12.2020).

Yenipınar U, Köşker H, Karacaoğlu S. 2014. Turizmde Yerel Yiyeceklerin Önemi ve Coğrafi İşaretleme: Van Oltu Peyniri. Journal of Tourism and Gastronomy Studies, 2(2): $13-23$. 